\title{
Streptobacillus moniliformis
}

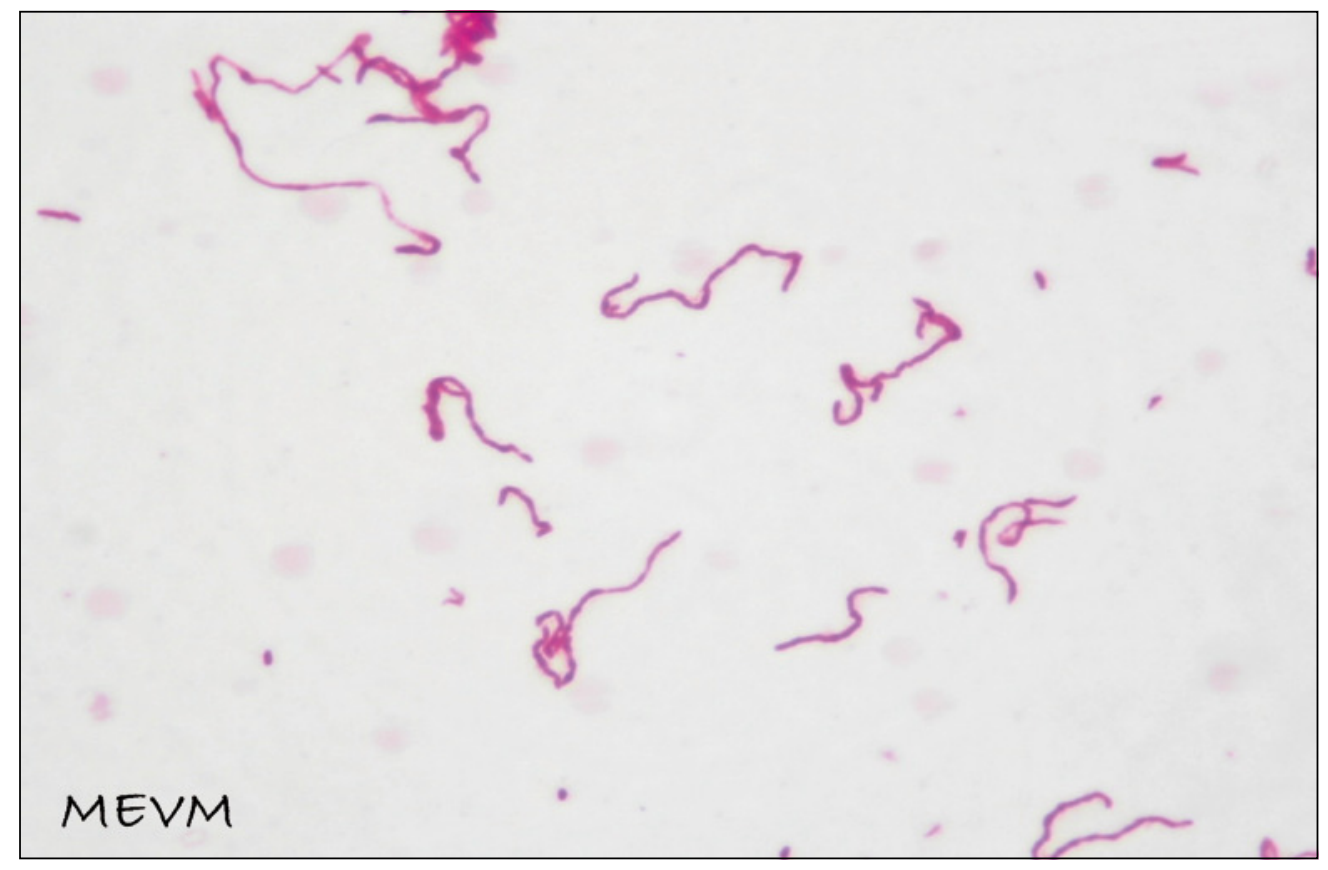

Figura 1. Aspecto al Gram: Bacilo gramnegativo.

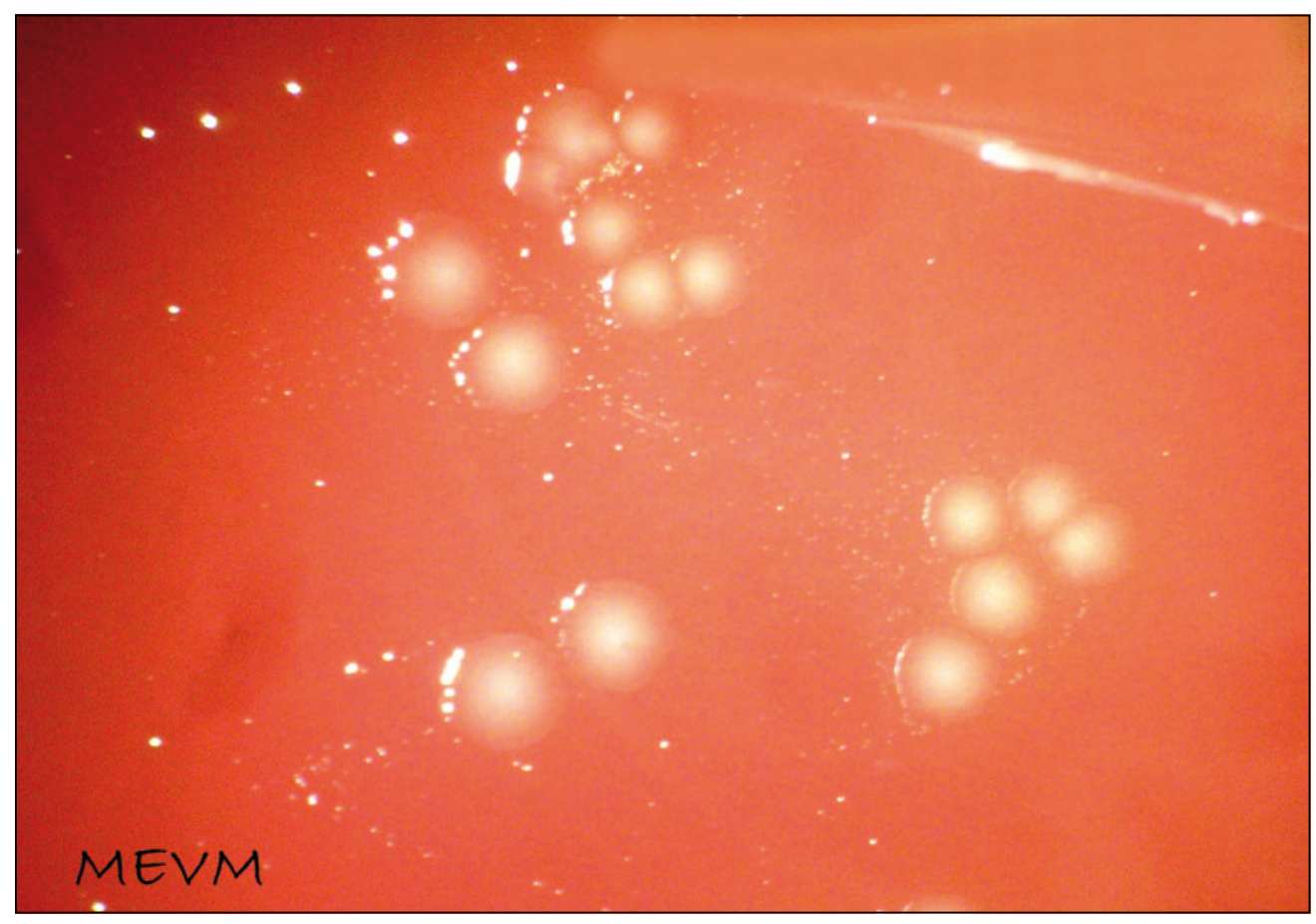

Figura 2. Aspecto de las colonias en agar sangre: grisáceas, circulares y brillantes. 


\section{Retrato Microbiológico}

\section{Streptobacillus moniliformis}

Streptobacillus moniliformis es un bacilo gramnegativo fastidioso que forma parte de la microbiota nasofaríngea de roedores. La infección humana se manifiesta como fiebre por mordedura de ratas (FMR) o fiebre de Haverhill (FH). La FMR se adquiere por la mordedura o arañazo, mientras que la FH se transmite por el consumo de agua o alimentos contaminados con heces de ratas. Ambas entidades son clínicamente similares y la principal diferencia es que la FH puede presentarse como brotes epidémicos.

El medio de cultivo de elección es el agar tripticasa soya enriquecido con $20 \%$ de suero bovino o equino, $15 \%$ de sangre ó 5\% de líquido ascítico. Las condiciones óptimas de crecimiento son en microaerofilia y humedad. Después de 48 a 72 horas de incubación, da origen a colonias circulares, convexas, grisáceas y brillantes, de 1-2 mm. Se observan al Gram como cocobacilos gramnegativos pleomórficos con tendencia a desarrollar bandas filamentosas con gránulos. Es oxidasa, catalasa y nitratasa negativa y la glucosa es acidificada débilmente. Puede ser identificada con sistemas comerciales o mediante reacción de polimerasa en cadena (RPC) la que ha comenzado a ser utilizada para el diagnóstico primario, demostrando ser más sensible y rápida que el cultivo.

El interés actual por las pequeñas mascotas ha producido una emergencia en el número de casos de esta zoonosis. La observación cuidadosa de las muestras y de los cultivos es necesaria para sospechar oportunamente una infección por este microorganismo.

In vitro, S. moniliformis es susceptible a penicilina, otros $\beta$-lactámicos, tetraciclinas, aminoglucósidos, quinolonas y macrólidos. En clínica se utiliza de primera línea bencilpenicilina.

\section{Referencia}

1.- Centers for Disease Control and Prevention. Rat-bite fever-New Mexico, 1996. MMWR Morbid Mortal Wkly Rep 1998; 47: 89-91.

M. Angélica Martínez T. Programa de Microbiología y Micología Facultad de Medicina Universidad de Chile María E. Valenzuela M., Daniella Pietrantoni F. Sección Bacteriología Clínica, Instituto de Salud Pública de Chile 